\title{
Proteomic and biochemical assays of glutathione-related proteins in susceptible and multiple herbicide resistant Avena fatua $\mathrm{L}$.
}

\section{Authors: Erin E. Burns, Barbara K. Keith, Mohammed Y. Refai, Brian Bothner, and William E. Dyer}

NOTICE: this is the author's version of a work that was accepted for publication in Pesticide Biochemistry \& Physiology Changes resulting from the publishing process, such as peer review, editing, corrections, structural formatting, and other quality control mechanisms may not be reflected in this document. Changes may have been made to this work since it was submitted for publication. A definitive version was subsequently published in Pesticide Biochemistry \& Physiology, VOL\# 140, (June 2017) DOI\#10.1016/j.pestbp.2017.06.007.

Burns, Erin E. , Barbara K. Keith, Mohammed Y. Refai, Brian Bothner, and William E. Dyer. "Proteomic and biochemical assays of glutathione-related proteins in susceptible and multiple herbicide resistant Avena fatua L.." Pesticide Biochemistry \& Physiology (June 2017). DOI: 10.1016/j.pestbp.2017.06.007.

Made available through Montana State University's ScholarWorks scholarworks.montana.edu 


\title{
Proteomic and biochemical assays of glutathione-related proteins in susceptible and multiple herbicide resistant Avena fatua L.
}

\author{
Erin E. Burns ${ }^{\text {a }}$, Barbara K. Keith ${ }^{\text {a }}$, Mohammed Y. Refai ${ }^{\mathrm{b}}$, Brian Bothner ${ }^{\mathrm{b}}$, William E. Dyer ${ }^{\mathrm{a}, *}$ \\ a Department of Plant Sciences E Plant Pathology, PO Box 173150, Montana State University, Bozeman, MT 59717, United States \\ b Department of Chemistry \& Biochemistry Research, PO Box 173400, Montana State University, Bozeman, MT 59717, United States
}

\begin{abstract}
A B S T R A C T
Extensive herbicide usage has led to the evolution of resistant weed populations that cause substantial crop yield losses and increase production costs. The multiple herbicide resistant (MHR) Avena fatua L. populations utilized in this study are resistant to members of all selective herbicide families, across five modes of action, available for A. fatua control in U.S. small grain production, and thus pose significant agronomic and economic threats. Resistance to ALS and ACCase inhibitors is not conferred by target site mutations, indicating that non-target site resistance mechanisms are involved. To investigate the potential involvement of glutathione-related enzymes in the MHR phenotype, we used a combination of proteomic, biochemical, and immunological approaches to compare their constitutive activities in herbicide susceptible (HS1 and HS2) and MHR (MHR3 and MHR4) A. fatua plants. Proteomic analysis identified three tau and one phi glutathione $S$-transferases (GSTs) present at higher levels in MHR compared to HS plants, while immunoassays revealed elevated levels of lambda, phi, and tau GSTs. GST specific activity towards 1-chloro-2,4-dinitrobenzene was 1.2-fold higher in MHR4 than in HS1 plants and 1.3- and 1.2-fold higher in MHR3 than in HS1 and HS2 plants, respectively. However, GST specific activities towards fenoxaprop-P-ethyl and imazamethabenz-methyl were not different between untreated MHR and HS plants. Dehydroascorbate reductase specific activity was 1.4-fold higher in MHR than HS plants. Pretreatment with the GST inhibitor NBD-Cl did not affect MHR sensitivity to fenoxaprop-P-ethyl application, while the herbicide safener and GST inducer mefenpyr reduced the efficacy of low doses of fenoxaprop-P-ethyl on MHR4 but not MHR3 plants. Mefenpyr treatment also partially reduced the efficacy of thiencarbazone-methyl or mesosulfuron-methyl on MHR3 or MHR4 plants, respectively. Overall, the GSTs described here are not directly involved in enhanced rates of fenoxaprop-P-ethyl or imazamethabenz-methyl metabolism in MHR A. fatua. In stead, we propose that the constitutively elevated GST proteins and related enzymes in MHR plants are representative of a larger, more global suite of abiotic stress-related changes.
\end{abstract}

\section{Introduction}

Herbicide resistance is a rapidly growing worldwide problem that causes significant crop yield losses, increases production costs, and threatens our ability to successfully manage weed populations $[1,2]$. Resistance can be conferred by target site overexpression or mutations that alter herbicide binding, or non-target site resistance (NTSR) mechanisms like enhanced rates of herbicide metabolism, reduced absorption/translocation, sequestration, or changes in generalized abiotic stress defense networks [3]. Multiple herbicide resistance (MHR), in which weeds are resistant to two or more unrelated herbicides, is a particularly ominous development in many cropping systems worldwide, and threatens the very basis of herbicidal weed management.
Avena fatua (Poaceae, Pooideae, Aveneae; wild oat) is an annual, allohexaploid, predominantly self-pollinating monocot that is ranked as one of the world's worst weed species [4]. It is particularly welladapted to temperate regions of Europe and North America, and infests over 11 million ha of cropland in the Northern Great Plains alone [5]. A. fatua populations that are resistant to one or more herbicides have been reported in the USA [6-8] and elsewhere [1]. We recently described the A. fatua MHR3 and MHR4 populations that are resistant to the acetylCoA carboxylase (ACCase) inhibitors fenoxaprop-P-ethyl, tralkoxydim, and pinoxaden, the acetolactate synthase (ALS) inhibitors imazamethabenz-methyl and flucarbazone, the growth inhibitor difenzoquat, the photosystem I inhibitor paraquat (MHR3 only), and the very long chain fatty acid (VLCFA) biosynthesis inhibitor triallate, with resistant/susceptible $\mathrm{ED}_{50}$ ratios ranging from 1.4 to 57 [6,9]. The MHR A. fatua populations are thus resistant to members of all selective herbicide families available for A. fatua control in U.S. small grain production. Resistance to ALS- and ACCase-inhibiting herbicides is not 
due to known target site mutations, and the cytochrome P450 monooxygenase inhibitor malathion partially reversed the resistance phenotype for several herbicides [6], indicating that NTSR mechanisms are involved.

The central component of plant response to abiotic stresses like herbicides is activation of the xenome, or the xenobiotic detection, transport, and detoxification network [10]. Glutathione (GSH)-related enzymes such as glutathione S-transferases (GSTs) and others are critical xenome players that are involved in enhanced degradation rates of several herbicides (reviewed in [11,12]). Compounds like the herbicide safener and GST inducer mefenpyr $[13,14]$ and the GST inhibitor 4chloro-7-nitrobenzoxadiazole (NBD-Cl) $[15,16]$ have proven invaluable in dissecting the contributions of GSTs in herbicide metabolism and MHR.

Our previous work showing that enhanced metabolism was likely involved in A. fatua resistance to several herbicides [6] led us to investigate the potential involvement of GSH-related enzymes in the MHR phenotype. We used a combination of proteomic, biochemical, and immunological approaches to compare the enzymes of GSH conjugation and related activities in HS and MHR A. fatua plants.

\section{Materials and methods}

\subsection{Plant material}

The MHR3 and MHR4 populations were derived from seeds collected in 2006 from two A. fatua populations not controlled by $60 \mathrm{~g}$ a.i. ha ${ }^{-1}$ pinoxaden (Axial, Syngenta Crop Protection; ACCase inhibitor) in two production fields separated by approximately $8 \mathrm{~km}$ in Teton County, Montana, USA. Field-collected seeds (about $90 \%$ of which were resistant to $60 \mathrm{~g}$ a.i. ha ${ }^{-1}$ pinoxaden, data not shown) were subjected to two generations of recurrent group selection (50 plants each generation) by spraying with the same dose of pinoxaden, after which $100 \%$ of plants were confirmed to be homozygous resistant to pinoxaden via dose response experiments $[6,17]$. From each generation of 50 plants, all seeds were harvested and a random selection of 50 seeds was used to initiate the next generation. The herbicide susceptible population HS1 was derived from seeds collected from untreated border plants in an adjacent field, and was subsequently confirmed to be $100 \%$ susceptible to the herbicides used in these studies [17]. A second susceptible population, HS2, is the inbred nondormant SH430 line used in seed dormancy research $[18,19]$. Plants were grown under a 16-hr photoperiod of natural sunlight supplemented with mercury vapor lamps $\left(165 \mu \mathrm{mol} \mathrm{m} \mathrm{m}^{-2} \mathrm{~s}^{-1}\right)$ at $25 \pm 4{ }^{\circ} \mathrm{C}$ in standard greenhouse soil mix [1:1:1 (by vol) Bozeman silt loam:Sunshine mix \#12 (Sun Gro Horticulture, Inc., Bellvue, WA):perlite] and fertilized weekly with Jack's water soluble 20 N-20 P-20 K (JR Peters Inc., Allentown, PA). All plants for each experiment were grown on the same greenhouse bench and were harvested in mid-morning to minimize environmental- and circadianinduced changes in protein levels.

\subsection{GSH affinity chromatography}

Shoot tissue (250 g) from fully tillered (BBCH stage 29) HS1 and MHR4 plants was ground under liquid nitrogen and suspended in ice cold extraction buffer (EB) containing 0.1 M Tris $\mathrm{HCl}$ (pH 7.5), $2 \mathrm{mM}$ EDTA, 1 mM DTT, 1 mM PMSF, and 5\% (w/v) PVPP. The slurries were homogenized (Polytron Homogenizer, Brinkman Instruments, Westbury NY) for 4 min on ice and filtered through Miracloth (EMD Millipore, Merck KGaA, Darmstadt, Germany). The filtrates were centrifuged at $19,600 \times g$ for $20 \mathrm{~min}$ at $4{ }^{\circ} \mathrm{C}$ and the supernatants subjected to $0-80 \%$ ammonium sulfate precipitation at $0{ }^{\circ} \mathrm{C}$. After centrifugation at $14,300 \times \mathrm{g}$ for $15 \mathrm{~min}$ at $4{ }^{\circ} \mathrm{C}$, the resulting protein pellets were redissolved in EB and dialyzed against the same buffer for $16 \mathrm{~h}$ at $4{ }^{\circ} \mathrm{C}$. Following addition of Triton X-100 to $1 \%(\mathrm{v} / \mathrm{v})$, protein samples (10 $\mathrm{mg} \mathrm{ml}^{-1}$ ) were subjected to GSH-agarose (Sigma-Aldrich G4510) affinity chromatography according to manufacturer's instructions. GSH-binding proteins were eluted with $10 \mathrm{mM}$ reduced GSH, precipitated twice with acetone at $-20{ }^{\circ} \mathrm{C}$ overnight and resuspended in DIGE buffer (7 M urea, $2 \mathrm{M}$ thiourea, $30 \mathrm{mM}$ Tris $\mathrm{pH} 8.5,4 \%$ [w/v] CHAPS, 1X protease inhibitor and nuclease mix [GE Healthcare Life Sciences, Pittsburgh, PA], and $0.1 \%$ [w/v] bromophenol blue) at $2 \mathrm{mg} \mathrm{ml}^{-1}$. Protein concentrations were determined [20] using bovine serum albumin (BSA) fraction $\mathrm{V}$ as standard.

\subsection{D-DIGE}

Two-dimensional difference gel electrophoresis (2D-DIGE) was initiated by minimal fluorescent labeling of lysine side-chains ( 1 per 100 ) with $N$-hydroxysuccinimide ester cyanine dyes (Z-CyDyes; ZCy3, Z-Cy5, Z-Cy2; [21]) according to the manufacturer's protocol (GE Healthcare Bio-Sciences Corp. Piscataway, NY). Briefly, GSH affinity chromatography extracts containing $50 \mu$ protein, were labeled separately on ice with 400 pmol of either Z-Cy3 or Z-Cy5 Cydye DIGE fluors dissolved in DMF. The internal standard, an equimolar mixture of all protein extracts, was labeled with Z-Cy2. Labeling reactions were quenched with $1 \mu \mathrm{l}$ of $10 \mathrm{mM}$ lysine, held on ice for $10 \mathrm{~min}$, combined appropriately (ex. HS1-Z-Cy3, MHR4-Z-Cy5, and internal standard-ZCy2), diluted to a final volume of $450 \mu \mathrm{l}$ with isoelectric focusing (IEF) buffer (DIGE buffer containing $50 \mathrm{mM}$ DTT and 0.5\% (v/v) IPG buffer 3-11 NL [GE Healthcare Bio-Sciences Corp. Piscataway, NY]), and incubated for $1 \mathrm{~h}$ at room temperature. IEF and SDS-PAGE followed the methods of Maaty, Selvig, Ryder, Tarlykov, Hilmer, Heinemann, Steffens, Snyder, Ortmann and Movahed [22].

\subsubsection{Image acquisition and analysis}

Gels were scanned using a Typhoon Trio Imager according to the manufacturer's protocol (GE Healthcare Bio-Sciences Corp. Piscataway, NY 08855) at $100 \mu \mathrm{m}$ resolution and $640 \mathrm{~V}$ for PMT. Images were subjected to an automated difference in-gel analysis using Progenesis SameSpots v 3.0.2 software (Nonlinear Dynamics Ltd. Newcastle, UK). Individual gel spots were co-detected as DIGE image pairs and linked to the corresponding in-gel Z-Cy2 standard to allow between-gel comparisons and statistical analyses. Gels used for protein identification contained $400 \mu \mathrm{g}$ of protein each and were stained with colloidal coomassie stain [23], destained in $10 \%$ acetic acid, and stored at $4{ }^{\circ} \mathrm{C}$ in $1 \%$ acetic acid until spot excision.

\subsubsection{Protein mass determination and analysis}

Protein spots of interest were excised, digested with porcine trypsin (Promega Corp. Madison, WI 53711), and eluted as described in Shevchenko, Tomas, Havli, Olsen and Mann [24]. The resulting peptides were subjected to mass analysis performed on Bruker maXis Impact with Dionex 3000 nano-uHPLC controlled with Chromeleon Xpress (2.13 for Hystar). Briefly, samples of $20 \mu$ l each were processed via Dionex Ultimate 3000 nano UHPLC, with an Acclaim PepMap100 C18 column $(300 \mu \mathrm{m} \times 5 \mathrm{~mm})$ used for both trapping and final peptide separation. Chromatography was as follows: solvent consisted of $\mathrm{H}_{2} \mathrm{O}$ with $0.1 \%(\mathrm{v} / \mathrm{v})$ formic acid for channel " $\mathrm{A}$ " and acetonitrile for channel "B". Following sample trapping for $2 \mathrm{~min}$ at a flow rate of $20 \mu \mathrm{min}^{-1}$, the HPLC valve was switched to elution position. From $0.0 \mathrm{~min}$ to $2.5 \mathrm{~min}$, the elution solvent pump composition was held at $5 \%$ B. From 2.5 to $20 \mathrm{~min}$, the elution solvent gradient was linearly changed from $5 \%$ to $30 \%$ B. From 20 to 23 min, the gradient was ramped from 30\% to 95\% B. From 23 to $28 \mathrm{~min}$, the solvent was held at $95 \% \mathrm{~B}$, and from $28 \mathrm{~min}$ to 30 min the solvent was linearly ramped from $95 \%$ B to $7 \%$ B. During the entire run, the loading pump solvent was held at $20 \mu \mathrm{min}^{-1}$ of $97 \%$ water, $3 \%$ acetonitrile, and $0.1 \%$ formic acid. The mass spectrometer used was a Bruker maXis Impact with CaptiveSpray ESI source with a resolution and accuracy of approximately 40,000 and $<5$ ppm, respectively. Spectra were collected in positive mode from 200 to $2500 \mathrm{~m} / \mathrm{z}$ at a maximum rate of $2 \mathrm{~Hz}$ for both precursor and fragment spectra 
and with adaptive acquisition time for highly-abundant ions. The resulting data files were processed to select fragmentation spectra with Bruker DataAnalysis and exported as MGF files.

Protein identification followed the methods outlined in Mason, Hilmer, Maaty, Reeves, Grieco, Bothner and Fischer [25] using SearchGUI (V3.0.3) and Peptideshaker (V1.12.3), initiated by generating a custom protein sequence file (.FASTA) from the Oryza sativa subsp.japonica (retrieved 2016; http://www.UniProt.org; containing 121,989 entries) and Brachypodium distachyon (retrieved 2016; http://www. UniProt.org; containing 50,507 entries) databases. Sequences for potential contaminants human keratin (retrieved 2016; http://www.UniProt. org; containing 49 entries) and porcine trypsin (retrieved 2016; http:// www.UniProt.org; containing 1 entry) were added to the sequence file to create a final target-decoy library. The library was queried against data files using the following search parameters: up to two missed cleavages allowed, precursor charges $+2 ;+3 ;+4$, precursor ion mass tolerance $30 \mathrm{ppm}$, and fragmentation mass tolerance of $0.5 \mathrm{Da}$. Post translational modifications were defined as oxidation of M, acetylation of N-terminus, and carboxylation of C-terminus. Two or more significant peptides with an FDR $\leq 1.0 \%$ (PeptideShaker software [26]) were required for annotation of each protein from the PaxDb database [27] as accessed through UniProtKB and the Rice Genome Annotation Project (http://rice.plantbiology.msu.edu/).

\subsection{Enzyme assays}

Proteins were extracted from four replicate three-leaf stage $(\mathrm{BBCH}$ stage 13) HS and MHR plants as described above except using a 0-80\% ammonium sulfate precipitation step and desalting with Zeba ${ }^{\mathrm{TM}}$ spin desalting columns (ThermoFischer Scientific, Waltham, MA). Samples were held on ice for immediate use or stored at $-80^{\circ} \mathrm{C}$. Total protein concentrations were determined as described above and results are expressed as enzyme specific activities.

\subsubsection{Glutathione S-transferase}

GST activity towards 1-chloro-2,4-dinitrobenzene (CDNB) was determined as described in Habig, Pabst and Jakoby [28] in $0.1 \mathrm{M} \mathrm{KPO}_{4}$ buffer ( $\mathrm{pH}$ 7.6) containing $1 \mathrm{mM}$ reduced glutathione (GSH), $1 \mathrm{mM}$ $\mathrm{CDNB}$, and $37.5 \mu \mathrm{g}$ of plant protein. Enzyme activity was determined by measuring the increase in absorbance at $340 \mathrm{~nm}$ over $5 \mathrm{~min}$ at $21^{\circ} \mathrm{C}$.

\subsubsection{Glutathione peroxidase}

Glutathione peroxidase (GPx) activity was determined as described in Weydert and Cullen [29] in $50 \mathrm{mM}$ Tris- $\mathrm{HCl}$ ( $\mathrm{pH}$ 7.6) containing $5 \mathrm{mM}$ EDTA, $1 \mathrm{mg} \mathrm{ml}^{-1}$ BSA fraction $\mathrm{V}, 0.2 \mathrm{mM}$ NADPH, $1 \mathrm{mM} \mathrm{GSH}$, $1 \mathrm{U} \mathrm{ml}^{-1}$ glutathione reductase, $315.8 \mu \mathrm{g}$ protein extract, and either $1.5 \mathrm{mM}$ cumene hydroperoxide or linoleic acid hydroperoxide. Linoleic acid hydroperoxide was synthesized according to Edwards and Dixon [30]. Enzyme activity was determined by measuring the decrease in absorbance at $340 \mathrm{~nm}$ over $5 \mathrm{~min}$ at $21^{\circ} \mathrm{C}$.

\subsubsection{Dehydroascorbate reductase}

Dehydroascorbate reductase (DHAR) activity was determined as described in Dixon, Davis and Edwards [31] in $90 \mathrm{mM} \mathrm{KPO}_{4}$ buffer ( $\mathrm{pH} 6.5$ ) containing $5 \mathrm{mM} \mathrm{GSH}, 0.5 \mathrm{mM}$ dehydroascorbate, and $356 \mu \mathrm{g}$ protein extract. Enzyme activity was determined by measuring the increase in absorbance at $265 \mathrm{~nm}$ over $120 \mathrm{~s}$ at $21^{\circ} \mathrm{C}$.

\subsubsection{2-Hydroxyethyl disulfide}

2-Hydroxyethyl disulfide (HED) thioltransferase activity was determined as described in Dixon, Davis and Edwards [31] in $0.1 \mathrm{M}$ Tris- $\mathrm{HCl}$ (pH 7.8) containing $2 \mathrm{mM}$ EDTA, $1 \mathrm{mM} \mathrm{GSH}, 0.6 \mathrm{U} \mathrm{ml}^{-1}$ glutathione reductase, $0.7 \mathrm{mM}$ HED, $0.25 \mathrm{mM} \mathrm{NADPH}$, and $480 \mu \mathrm{g}$ protein extract. Following HED addition, the assay mixture was incubated at $30{ }^{\circ} \mathrm{C}$ for $3 \mathrm{~min}$, after which enzyme activity was determined by measuring the decrease in absorbance at $340 \mathrm{~nm}$ over $120 \mathrm{~s}$ at $21^{\circ} \mathrm{C}$.

\subsection{HPLC assays}

Proteins were extracted from four replicate three-leaf stage $(\mathrm{BBCH}$ stage 13) HS1 and MHR4 plants as described above except the extraction buffer contained $100 \mathrm{mM} \mathrm{KPO}_{4}$ (pH 7.0), 1 mM DTT, 2 mM EDTA, and $500 \mathrm{mM} \mathrm{NaCl}$. Total protein concentrations were determined as described above. GST activity assays $(250 \mu \mathrm{l})$ contained $50 \mathrm{mM} \mathrm{KPO}_{4}$ buffer (pH 7.0), $25 \mu \mathrm{g}$ fenoxaprop-P-ethyl (96.6\% purity; Bayer Cropscience) or fenoxaprop-acid (98\% purity; Sigma-Aldrich) or $25 \mu \mathrm{g}$ imazamethabenz-methyl (90\% purity; American Cyanamid Company) or imazamethabenz-acid, $1 \mathrm{mM}$ reduced glutathione, and $100 \mu \mathrm{g}$ plant protein. Blank assays contained $50 \mathrm{mM} \mathrm{KPO}_{4}$ buffer ( $\mathrm{pH} 7.0$ ), extraction buffer, fenoxaprop-P-ethyl and fenoxaprop acid or imazamethabenzmethyl and imazamethabenz acid (synthesized from imazamethabenzmethyl according to [32]). Assays were incubated at $30 \mathrm{C}$ for 30,60 , 180,300 , or $1440 \mathrm{~min}$, reactions were stopped by addition of an equal volume of methanol, held at $-20{ }^{\circ} \mathrm{C}$ for $4 \mathrm{~h}$, and centrifuged for 20 min at $14,000 \times g$ at $4{ }^{\circ} \mathrm{C}$. Supernatants were subjected to HPLC separation using a Phenomenx PLRP-S $150 \mathrm{~mm}$ column at $60^{\circ} \mathrm{C}$ with a flow rate of $0.5 \mathrm{ml} \mathrm{min}^{-1}$ on an Agilent 1100 binary pump with an Agilent UV detector at $180 \mathrm{~nm}$. For fenoxaprop-P-ethyl assays, Solvent A was water containing $0.1 \%(\mathrm{v} / \mathrm{v})$ formic acid and solvent $B$ was acetonitrile. Following column equilibration for $1 \mathrm{~min}$ at $20 \% \mathrm{~B}$, the sample was injected and a gradient was linearly ramped from $60 \%$ to $90 \%$ B over the $10 \mathrm{~min}$ run. All other HPLC methods followed those of Marles, Devine and Hall [33].

Mass analysis of herbicide-GSH conjugates was conducted using an Agilent 6538 Q-TOF with dual-ESI source. Resolution was approximately 20,000, accuracy was $<5 \mathrm{ppm}$, and source parameters were: drying gas $12 \mathrm{~L} \mathrm{~min}^{-1}$, nebulizer $55 \mathrm{psi}$, capillary voltage $3500 \mathrm{~V}$, and capillary exit $120 \mathrm{~V}$. Spectra were collected in positive mode from 50 to $1000 \mathrm{~m} / \mathrm{z}$ at a rate of $2 \mathrm{~Hz}$. Resulting spectral data were processed using the Bruker Daltonics Compass data analysis 4.2 SR2 open lab CDS, Chemstation edition for LC and LCMS systems (Agilent Technologies rev C.01.05).

For enzyme and HPLC assays, linear mixed effects models were constructed to compare the rates of enzyme specific activity among populations. Models were fit using the lme function in R [34]. Differences in mean enzyme specific activities were separated using Tukey's HSD post hoc tests in the R lsmeans package.

\subsection{GST inducer and reversal experiments}

For GST inducer experiments, three-leaf stage (BBCH stage 13) HS and MHR seedlings were treated with five doses of the following technical grade (active ingredient only) herbicides with and without their safener (mefenpyr-diethyl) components: fenoxaprop-P-ethyl (Puma, Bayer CropScience), thiencarbazone-methyl (Varro, Bayer CropScience) plus $0.125 \%$ (v/v) nonionic surfactant, or mesosulfuron-methyl (Osprey, Bayer CropScience) plus $0.125 \%$ (v/v) nonionic surfactant. Technical grade herbicides and the safener were applied at $0,0.1 \times, 0.3 \times, 1 \times$, $3 \times$, and $6 \times$ doses, with $1 \times$ being the manufacturer's recommended application dose for small grains, which are $86 \mathrm{~g}$ a.i. ha ${ }^{-1}$ for fenoxapropP-ethyl, $5 \mathrm{~g}$ a.i. ha ${ }^{-1}$ for thiencarbazone-methyl, $15 \mathrm{~g}$ a.i. ha ${ }^{-1}$ for mesosulfuron-methyl. The $1 \times$ field dose of mefenpyr-diethyl used in this study was $30 \mathrm{~g}$ a.i. ha ${ }^{-1}$ for mesosulfuron-methyl and thiencarbazone-methyl treatments and $25.2 \mathrm{~g}$ a.i. ha ${ }^{-1}$ for fenoxaprop-P-ethyl treatments (safener dose information provided by Bayer CropScience). For GST inhibitor experiments, three-leaf stage (BBCH stage 13) HS and MHR seedlings were treated with $80 \mathrm{~g} \mathrm{ha}^{-1}$ 4-chloro-7-nitrobenzoxadiazole (NBD-Cl) plus $0.125 \%(\mathrm{v} / \mathrm{v})$ nonionic surfactant $48 \mathrm{~h}$ before application of $86 \mathrm{~g}$ a.i. ha ${ }^{-1}$ fenoxaprop-P-ethyl. All treatments were applied using a moving nozzle sprayer in $94 \mathrm{~L}$ water ha ${ }^{-1}$. When the spray solution had dried, plants were returned to the greenhouse conditions described above for 3 weeks, after which aboveground biomass was harvested, dried for 1 week at $40{ }^{\circ} \mathrm{C}$, and 
weighed. There were four biological replications of each herbicide dose, and the experiments were conducted twice.

To compare the effects of safener treatment within a herbicide application dose, linear mixed effects models were constructed with fixed effects for treatment and population and a random effect for experimental run. Models were fit using the lme function in R [34], and means were separated using Tukey's HSD post hoc tests. To compare GST inhibitor effects, linear mixed effects models were constructed with fixed effects for treatment and population and a random effect for experimental run. Models were fit using the lme function in R [34], and means were separated using Tukey's HSD post hoc tests.

\subsection{GST immunoassays}

\subsubsection{D PAGE}

Protein extracts ( $20 \mu \mathrm{g}$ per lane) obtained as described above were heated at $95^{\circ} \mathrm{C}$ for $5 \mathrm{~min}$ in $1 \times$ Laemmli SDS sample buffer [35] before being subjected to SDS-PAGE in $12.5 \%$ gels at $2.5 \mathrm{~mA} \mathrm{~cm}^{-1}$ for $3 \mathrm{~h}$ with water cooling.

\subsubsection{D PAGE}

Protein extracts obtained as described above and were subjected to the isoelectric focusing and electrophoresis methods of Hochstrasser, Harrington, Hochstrasser, Miller and Merril [36] with the following modifications. Proteins were precipitated with $10 \%(\mathrm{v} / \mathrm{v})$ TCA at $0{ }^{\circ} \mathrm{C}$, centrifuged at $14,000 \times \mathrm{g}$ for $2 \mathrm{~min}$ at $4{ }^{\circ} \mathrm{C}$, and the pellets washed twice with ether. After brief drying, the pellets were resuspended in IEF sample buffer ( $5 \mathrm{mg}$ protein $\mathrm{ml}^{-1}$ ) at $37^{\circ} \mathrm{C}$, centrifuged at $14,000 \times \mathrm{g}$ for $1 \mathrm{~min}$ at $25^{\circ} \mathrm{C}$, and the supernatant loaded onto $0.7 \mathrm{~mm}$ IEF capillary tube gels (30:0.8 acrylamide:piperazine diacrylamide) containing $4 \%$ (v/v) pH 3-10 and 1\% (v/v) pH 4-6 ampholytes (Bio-Rad 163-1112 and 163-1142). Isoelectric focusing was done for $16 \mathrm{~h}$ at $850 \mathrm{~V}$ with water cooling, and SDS-PAGE performed as described above.

\subsection{Immunoblots}

Proteins were electroblotted from SDS gels onto PVDF membrane (Pall Corporation, Radnor, PA) and probed with rabbit polyclonal antisera against either lambda [37], tau [38], or phi [39] GSTs diluted $1: 5000(\mathrm{v} / \mathrm{v})$ in blotto $(10 \%[\mathrm{w} / \mathrm{v}]$ nonfat dry powdered milk/phosphate-buffered saline $/ 0.001 \%[\mathrm{w} / \mathrm{v}]$ sodium azide) followed by detection with goat anti-rabbit IgG/alkaline phosphatase (Sigma-Aldrich AP132A) diluted 1:10,000 (v/v) in blotto. Densitometric analyses were performed using Image [40] to compare amounts of immunoreactive proteins among populations.

\section{Results}

\subsection{Proteomic analysis}

2D-DIGE was used to compare constitutive profiles of abundant, soluble GSH-binding proteins from untreated MHR4 and HS1 plants (Fig. 1, Table 1). Statistical analysis identified 33 differential spots corresponding to 24 unique proteins, identified here by the best annotation from UniProt and the Rice Genome Annotation Project. Of these, five proteins were detected at higher levels in MHR4 plants, including three tau class GSTs (OsGSTU1, OsGSTU5, OsGSTU27), one phi class GST (OsGSTF3), and an unclassified GST (Table 1). In addition to GSTs, eight other protein spots $(13,17,19-23,30)$ corresponding to five unique proteins were identified as GSH-binding proteins from non-plant systems (Table 1). DIGE gels also revealed 17 differential spots corresponding to 14 unique proteins with no known GSH-binding activity in plants (Table A.1).

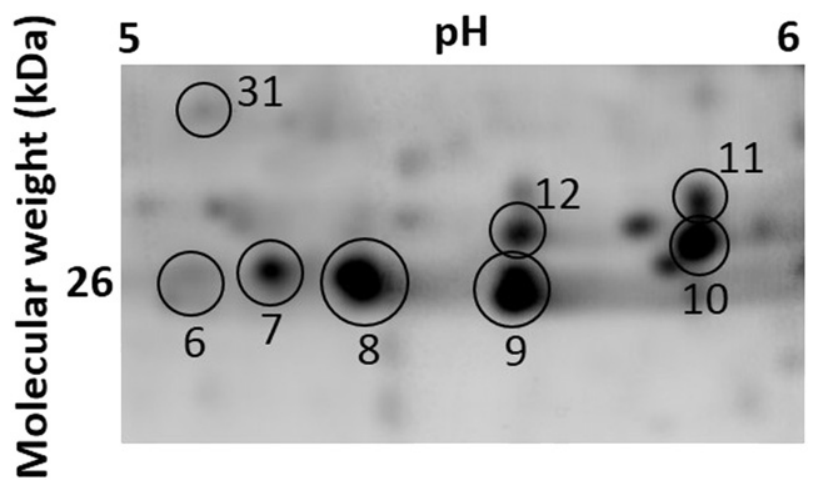

Fig. 1. Selected area of a two dimensional fluorescence difference electrophoresis gel of the Avena fatua GSH-affinity proteome. Numbered and additional spots were picked and proteins identified using in-gel proteolysis followed LC-MS/MS.

\subsection{Biochemical analysis}

\subsubsection{Enzyme assays}

GST specific activity towards CDNB (GST(CDNB)) was 1.2 -fold ( $\mathrm{p}=$ $0.018)$ higher in MHR4 than in HS1 plants and 1.3- $(p \leq 0.0001)$ and 1.2fold ( $\mathrm{p}=0.007$ ) higher in MHR3 than in HS1 and HS2 plants, respectively (Table 2). There were no differences in GST(CDNB) activity between MHR4 and HS2 plants, between HS1 and HS2 plants, or between MHR3 and MHR4 plants.

GST specific activity assays on fenoxaprop-P-ethyl were conducted using both fenoxaprop-P-ethyl and fenoxaprop acid to account for non-enzymatic GSH conjugation [41]. Metabolism of imazamethabenzmethyl in A. fatua [8] and other monocots proceeds mainly via glucose conjugation, although GSH conjugation of related herbicides is observed in other species [42]. For both herbicides, GST activities were very low and were not significantly different between untreated MHR4 and HS1 plants (Table 2). Mass analyses of fenoxaprop acid-glutathione and imazamethabenz acid-glutathione conjugates confirmed their molecular masses as 458.87 and 581.64, respectively.

DHAR specific activity was 1.4 -fold higher $(\mathrm{p} \leq 0.0001)$ in MHR versus HS plants, and there were no significant differences between HS1 and HS2 plants, or between MHR3 and MHR4 plants (Table 2). HED and GPx specific activities were not significantly different among any populations (Table 2). However, MHR plants had slightly but not significantly higher GPx activity on linoleic acid than HS plants.

\subsubsection{GST inducer}

There were no differences in mean dry weights (DWs) of HS1, HS2, and MHR3 plants treated with mesosulfuron-methyl alone as compared to plants treated with mesosulfuron-methyl plus the GST inducer mefenpyr at any herbicide dose (Table A.2). For MHR4, plant DW was significantly larger for plants treated with mesosulfuron-methyl plus mefenpyr, as compared to plants treated with mesosulfuron-methyl alone, at the $15 \mathrm{~g}$ a.i. ha ${ }^{-1}(\mathrm{p}=0.0947)$ and $45 \mathrm{~g}$ a.i. ha ${ }^{-1}(\mathrm{p}=$ 0.0499 ) doses. For thiencarbazone-methyl, there were no differences in DWs of HS1, HS2, and MHR4 plants treated with herbicide alone as compared to plants treated with herbicide plus mefenpyr at any herbicide dose (Table A.2). However, MHR3 plants treated with thiencarbazone-methyl plus mefenpyr at $0.5 \mathrm{~g}$ a.i. $\mathrm{ha}^{-1}$ had significantly more DW ( $p=0.069$ ) than plants treated with thiencarbazonemethyl alone. For fenoxaprop-P-ethyl, there were no differences in DW of MRH4 plants treated with the herbicide alone or in combination with mefenpyr at any dose (Table A.2). In contrast, HS1, MHR3, and MHR4 plants treated with $8.6 \mathrm{~g}$ a.i. $\mathrm{ha}^{-1}$ fenoxaprop-P-ethyl plus mefenpyr had significantly more DW $(\mathrm{p} \leq 0.001, \mathrm{p}=0.024$, and $\mathrm{p}=$ 0.061 , respectively) than their counterparts treated with the same dose of herbicide alone. 
Table 1

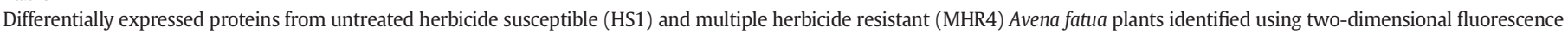
difference gel electrophoresis.

\begin{tabular}{|c|c|c|c|c|c|c|}
\hline $\begin{array}{l}\text { Spot } \\
\text { number }\end{array}$ & Uniprot & $\begin{array}{l}\text { Oryza sativa } \\
\text { number }\end{array}$ & Annotation & $\begin{array}{l}\text { Fold } \\
\text { change }^{\mathrm{a}}\end{array}$ & $\begin{array}{l}\text { Number of } \\
\text { peptides }\end{array}$ & Peptide sequences $^{\mathrm{b}}$ \\
\hline 6 & Q9FUE5 & Os09g0367700 & Glutathione S-transferase OsGSTU5 & 1.6 & 2 & $\begin{array}{l}\text { FWADYVDK } \\
\text { FWADYVDKKLFDCQTR }\end{array}$ \\
\hline 7 & Q9FUE5 & Os09g0367700 & Glutathione S-transferase OsGSTU5 & 3.1 & 2 & $\begin{array}{l}\text { DAAHEQAKRDMAEALGTLEA } \\
\text { FWADYVDKK }\end{array}$ \\
\hline 8 & Q10CE7 & Os03g0785900 & Glutathione S-transferase OsGSTU1 & 2.5 & 3 & $\begin{array}{l}\text { HLPSPEKVYDFVGVLK } \\
\text { HLPSPEKVYDFVGVLKK } \\
\text { EEKELVLLDFWVSPFGQR }\end{array}$ \\
\hline 9 & Q10CE7 & Os03g0785900 & Glutathione S-transferase OsGSTU1 & 1.8 & 2 & $\begin{array}{l}\text { HLPSPEKVYDFVGVLKK } \\
\text { ELVLLDFWVSPFGQR }\end{array}$ \\
\hline 10 & Q9FUD8 & Os03g0135300 & Glutathione S-transferase OsGSTF3 & 2.3 & 3 & $\begin{array}{l}\text { ATDMAVVEQNEAK } \\
\text { LQPFGQVPAFK } \\
\text { AAPVTVYGPMISPAVAR }\end{array}$ \\
\hline 11 & Q9FUD8 & Os03g0135300 & Glutathione $S$-transferase OsGSTF3 & 2.4 & 2 & $\begin{array}{l}\text { ATDMAVVEQNEAK } \\
\text { LQPFGQVPAFK }\end{array}$ \\
\hline 12 & Q60DP1 & Os03g0643700 & Glutathione $S$-transferase & 3.5 & 2 & $\begin{array}{l}\text { TLEAELGGRRYFGGGGEALGYVDVALAPFTAWFATYER } \\
\text { FIDEEFAGVGEPLLPA }\end{array}$ \\
\hline 13 & B7ERQ1 & Os07g0638300 & Peroxiredoxin & 1.6 & 2 & $\begin{array}{l}\text { AIKQLNMVDPDEKD } \\
\text { IPPGVSDDEAKEKFPQGFDTAD }\end{array}$ \\
\hline 17 & I1GW31 & Os04g0628100 & Polyubiquitin & -7.5 & 2 & $\begin{array}{l}\text { ESTLHLVLR } \\
\text { DKEGIPPDQQRLIFAGKQLEDGRT }\end{array}$ \\
\hline 19 & I1IN47 & Os11g0171300 & $\begin{array}{l}\text { Fructose-bisphosphate aldolase, } \\
\text { chloroplast precursor }\end{array}$ & -5.5 & 10 & $\begin{array}{l}\text { IVDILVEQGIVPGIK } \\
\text { IVDILVEQGIVPGIKVDK } \\
\text { KIVDILVEQGIVPGIK } \\
\text { LDSIGLENTEANR } \\
\text { RLDSIGLENTEANR } \\
\text { TLLVTPPGLGNYISGAILFEETLYQSTVDGK } \\
\text { TLLVTPPGLGNYISGAILFEETLYQSTVDGKK } \\
\text { TVVSIPNGPSELAVK } \\
\text { TWGGRPENVAAAQEALLLR } \\
\text { YAAISQDNGLVPIVEPEILLDGEHGIDR }\end{array}$ \\
\hline 20 & I1IN47 & Os11g0171300 & $\begin{array}{l}\text { Fructose-bisphosphate aldolase, } \\
\text { chloroplast precursor }\end{array}$ & 7.7 & 11 & $\begin{array}{l}\text { ASAYADELVK } \\
\text { EAAWGLAR } \\
\text { IVDILVEQGIVPGIK } \\
\text { IVDILVEQGIVPGIKVDK } \\
\text { KIVDILVEQGIVPGIK } \\
\text { LDSIGLENTEANR } \\
\text { RLDSIGLENTEANR } \\
\text { TLLVTPPGLGNYISGAILFEETLYQSTVDGK } \\
\text { TVVSIPNGPSELAVK } \\
\text { TWGGRPENVAAAQEALLLR } \\
\text { YAAISQDNGLVPIVEPEILLDGEHGIDR }\end{array}$ \\
\hline 21 & I1IN47 & Os11g0171300 & $\begin{array}{l}\text { Fructose-bisphosphate aldolase, } \\
\text { chloroplast precursor }\end{array}$ & -6.9 & 15 & $\begin{array}{l}\text { AKANSLAQLGK } \\
\text { ANSLAQLGK } \\
\text { ASAYADELVK } \\
\text { IVDILVEQGIVPGIK } \\
\text { IVDILVEQGIVPGIKVDK } \\
\text { KIVDILVEQGIVPGIK } \\
\text { KIVDILVEQGIVPGIKVDK } \\
\text { LDSIGLENTEANR } \\
\text { QAYRTLLVTPPGLGNYISGAILFEETLYQSTVDGK } \\
\text { RLDSIGLENTEANR } \\
\text { TLLVTPPGLGNYISGAILFEETLYQSTVDGK } \\
\text { TLLVTPPGLGNYISGAILFEETLYQSTVDGKK } \\
\text { TVVSIPNGPSELAVK } \\
\text { TWGGRPENVAAAQEALLLR } \\
\text { YAAISQDNGLVPIVEPEILLDGEHGIDR }\end{array}$ \\
\hline 22 & Q6Z8F4 & Os02g0698000 & Phosphoribulokinase & -8.2 & 11 & $\begin{array}{l}\text { ANDFDLMYEQVK } \\
\text { DLYEQIIAER } \\
\text { FYGEVTQQMLK } \\
\text { HADFPGSNNGTGLFQTIVGLK } \\
\text { IRDLYEQIIAER } \\
\text { KPDFDAFIDPQK } \\
\text { KPDFDAFIDPQKQYADAVIEVLPTQLIPDDNEGK } \\
\text { KPDFDAFIDPQKQYADAVIEVLPTQLIPDDNEGKVLR } \\
\text { LDELIYVESHLSNLSTK } \\
\text { QYADAVIEVLPTQLIPDDNEGK } \\
\text { QYADAVIEVLPTQLIPDDNEGKVLR }\end{array}$ \\
\hline 23 & Q6Z8F4 & Os02g0698000 & Phosphoribulokinase & -7.3 & 10 & $\begin{array}{l}\text { ANDFDLMYEQVK } \\
\text { DLYEQIIAER } \\
\text { FYGEVTQQMLK } \\
\text { HADFPGSNNGTGLFQTIVGLK } \\
\text { IRDLYEQIIAER }\end{array}$ \\
\hline
\end{tabular}


Table 1 (continued)

\begin{tabular}{|c|c|c|c|c|c|c|}
\hline $\begin{array}{l}\text { Spot } \\
\text { number }\end{array}$ & Uniprot & $\begin{array}{l}\text { Oryza sativa } \\
\text { number }\end{array}$ & Annotation & $\begin{array}{l}\text { Fold } \\
\text { change }^{a}\end{array}$ & $\begin{array}{l}\text { Number of } \\
\text { peptides }\end{array}$ & Peptide sequences ${ }^{\mathrm{b}}$ \\
\hline & & & & & & $\begin{array}{l}\text { KPDFDAFIDPQK } \\
\text { KPDFDAFIDPQKQYADAVIEVLPTQLIPDDNEGK } \\
\text { LDELIYVESHLSNLSTK } \\
\text { QYADAVIEVLPTQLIPDDNEGK } \\
\text { QYADAVIEVLPTQLIPDDNEGKVLR }\end{array}$ \\
\hline 30 & Q7XDC8 & Os10g0478200 & Malate dehydrogenase, cytoplasmic & -7.2 & 4 & $\begin{array}{l}\text { EFAPSIPEK } \\
\text { MDATAQELSEEK }\end{array}$ \\
\hline 31 & Q69LE6 & Os07g0168300 & Glutathione S-transferase OsGST27 & 2.6 & 2 & $\begin{array}{l}\text { TPLLVAWAER } \\
\text { EEEIGGGKSELLLA }\end{array}$ \\
\hline
\end{tabular}

a Positive and negative fold change values indicate higher and lower levels in MHR4 compared to HS1 plants, respectively.

b Italic letter indicates dehydrated post translational modification, underlined letter indicates ammonia loss post translational modification.

\subsubsection{GST inhibitor}

HS1 and HS2 plants treated with fenoxaprop-P-ethyl alone were significantly injured ( $\mathrm{p} \leq 0.0001$ ), and pre-treatment with the GST inhibitor NBD-Cl did not alter their sensitivity (Fig. 2). MHR3 plants were slightly but not significantly injured by treatment with fenoxaprop-Pethyl, while DWs of MHR4 plants were not reduced by this treatment. Pre-treatment of MHR plants with NBD-Cl did not affect their resistance to fenoxaprop-P-ethyl. As compared to all other treatments, DWs of both HS and MHR plants were significantly increased ( $\mathrm{p} \leq 0.0001)$ by treatment with NBD-Cl alone.

\subsection{GST immunoassays}

\subsubsection{D PAGE}

We used polyclonal antibodies raised against lambda, phi, and tau GSTs in immunoassays to detect immunoreactive proteins in HS and

Table 2

Glutathione-related enzyme activities from untreated multiple herbicide resistant (MHR3 and MHR4) and herbicide susceptible (HS1 and HS2) Avena fatua plants.

\begin{tabular}{lll}
\hline Enzyme $^{\mathrm{a}}$ & Population & Enzyme rate(SE) $^{\mathrm{b}}$ \\
\hline GST(CDNB) & HS1 & $93.8(3.9) \mathrm{a}^{\mathrm{c}}$ \\
& HS2 & $98.9(3.8) \mathrm{ab}$ \\
& MHR3 & $119.8(2.4) \mathrm{c}$ \\
GST(fenoxaprop-P-ethyl) & MHR4 & $112.1(7.9) \mathrm{bc}$ \\
GST(imazamethabenz-methyl) & HS1 & $-0.06(4.3) \mathrm{a}$ \\
GPX(cumene) & MHR4 & $15.2(10.0) \mathrm{a}$ \\
& HS1 & $3.0(26.7) \mathrm{a}$ \\
& MHR4 & $5.8(0.9) \mathrm{a}$ \\
GPX(linoleic) & HS1 & $27.1(1.5) \mathrm{a}$ \\
& HS2 & $29.4(1.5) \mathrm{a}$ \\
& MHR3 & $29.5(2.2) \mathrm{a}$ \\
DHAR & MHR4 & $28.4(0.8) \mathrm{a}$ \\
& HS1 & $10.7(1.2) \mathrm{a}$ \\
& HS2 & $11.0(1.2) \mathrm{a}$ \\
HED & MHR3 & $12.6(1.2) \mathrm{a}$ \\
& MHR4 & $14.1(1.5) \mathrm{a}$ \\
& HS1 & $230.3(5.3) \mathrm{a}$ \\
& HS2 & $224.0(3.0) \mathrm{a}$ \\
& MHR3 & $324.2(10.4) \mathrm{b}$ \\
& MHR4 & $323.3(12.0) \mathrm{b}$ \\
& HS1 & $82.4(6.0) \mathrm{a}$ \\
& HS2 & $60.2(3.0) \mathrm{a}$ \\
& MHR3 & $60.9(3.0) \mathrm{a}$ \\
& MHR4 & $79.0(12.0) \mathrm{a}$ \\
\hline
\end{tabular}

${ }^{\text {a }} \mathrm{GST}(\mathrm{CDNB})=$ glutathione $S$-transferase activity towards 1-chloro-2,4-dinitrobenzene, GST(fenoxaprop-P-ethyl) = glutathione S-transferase activity towards fenoxaprop-P-ethyl, $\mathrm{GST}$ (imazamethabenz-methyl) $=$ glutathione $S$-transferase activity towards imazamethabenz-methyl, GPx(cumene) = glutathione peroxidase activity towards cumene hydroperoxide, GPx(linoleic) = glutathione peroxidase activity towards linoleic acid hydroperoxide, DHAR = dehydroascorbate reductase, HED = 2-Hydroxyethyl disulfide.

b Enzyme specific activities for GST(CDNB), GPx(cumene), GPx(linoleic), DHAR, and HED assays are expressed in nkat $\mathrm{mg}$ fresh weight ${ }^{-1} \mathrm{~min}^{-1}$, enzyme rates for GST(fenoxaprop-Pethyl) and GST(imazamethabenz-methyl) are expressed in ng mg fresh weight ${ }^{-1} \mathrm{~min}^{-1}$.

c Means within an enzyme activity followed by the same letter are not significantly different $(\mathrm{p} \leq 0.05)$.
MHR A. fatua plants (Fig. 3a). These antibodies have been successfully used to identify GST orthologs in Triticum aestivum [43,44], A. myosuroides [41,45], and other species.

Antibodies to lambda GSTs recognized 29, 27, and $25 \mathrm{kDa}$ proteins in A. fatua plants (Fig. 3a). Levels of the $29 \mathrm{kDa}$ protein were 2.2- and 6.1fold higher in MHR3 than in HS1 and HS2 plants, respectively. Similarly, levels of the $29 \mathrm{kDa}$ protein were 1.7- and 4.8-fold higher in MHR4 than in HS1 and HS2 plants, respectively. The 27 and $25 \mathrm{kDa}$ proteins were not detectable in either HS population under these conditions.

Four A. fatua proteins of $28,28.5,26$, and $25 \mathrm{kDa}$ were recognized by anti-tau GST antibodies (Fig. 3a). Levels of the $28 \mathrm{kDa}$ protein were 2.1-, 2.3-, and 4.6-fold higher in HS2, MHR3, and MHR4 plants compared to HS1 plants, respectively. Levels of the other tau immunoreactive proteins were similar between HS and MHR plants.

Anti-phi GST antibodies recognized four proteins of 29, 28.5, 27, and $26 \mathrm{kDa}$ in A. fatua plants (Fig. 3a). Levels of the $29 \mathrm{kDa}$ protein were 4.7and 5.9-fold higher in MHR3 than in HS1 and HS2 plants, respectively. This protein was also 6.9- and 8.6-fold higher in MHR4 than in HS1 and HS2 plants, respectively. Levels of the $28.5 \mathrm{kDa}$ protein were 1.8 and 3.0-fold higher in MHR3 than in HS1 and HS2 plants, respectively. The $28.5 \mathrm{kDa}$ protein was also present at 2.7- and 4.4-fold higher levels in MHR4 plants as compared to HS1 and HS2 plants, respectively. Levels of the 27 and $26 \mathrm{kDa}$ phi immunoreactive proteins were similar among plants of all populations.

\subsubsection{D PAGE}

Differential levels of the $29 \mathrm{kDa}$ phi GST protein were further examined using 2D electrophoresis and immunoblots (Fig. 3b). The $29 \mathrm{kDa}$ protein was resolved into two proteins (arrows) with pIs of approximately 4 and 6 that were detected in MHR3 but not HS2 plants. Significantly, amounts of the proteins recognized by anti-lambda, -tau,

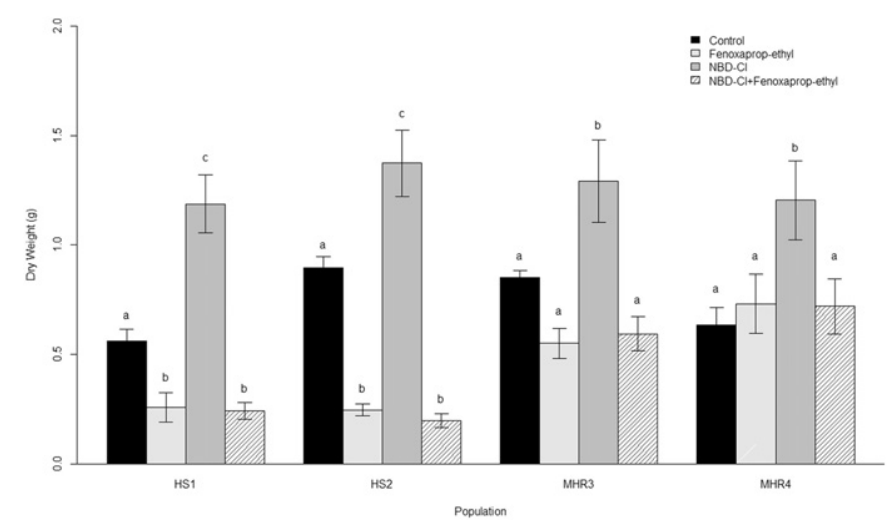

Fig. 2. Mean dry weight (g) of herbicide susceptible (HS1 and HS2) and multiple herbicide resistant (MHR3 and MHR3) Avena fatua plants treated with fenoxaprop-P-ethyl, the GST inhibitor NBC-Cl, or fenoxaprop-P-ethyl plus NBC-Cl. Means within a population followed by the same letter are not significantly different $(p \leq 0.05)$. 




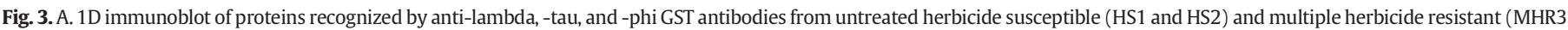

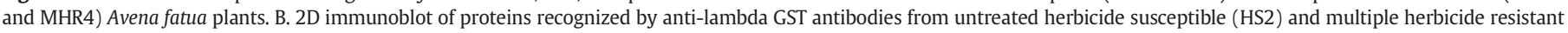
(MHR3) plants. Arrows indicate protein spots not detected in HS2.

and -phi GST antibodies did not change in HS or MHR plants $24 \mathrm{~h}$ after treatment with recommended field use doses of $94 \mathrm{~g}$ a.i. ha ${ }^{-1}$ imazamethabenz-methyl, $106 \mathrm{~g}$ a.i. ha ${ }^{-1}$ difenzoquat, or $86 \mathrm{~g}$ a.i. ha ${ }^{-1}$ fenoxaprop-P-ethyl (data not shown).

\section{Discussion}

Proteomic comparisons have been used by a number of laboratories to investigate changes in GSH-related proteins associated with xenome activation. In most cases, GSH-related enzymes are induced or otherwise modified rapidly after the imposition of stress, illustrating the central role of redox maintenance. For example, 2D-DIGE analyses of $O$. sativa response to bentazon treatment [46] and Anabena spp. tolerance to butachlor [47] demonstrated the upregulation of several xenome enzymes including GSTs. Similar comparisons identified specific phi and tau GSTs that were induced by the herbicide safener benoxacor or copper [48]. We used a similar approach, but instead compared constitutive levels of GSH-binding proteins in MHR and HS plants in the absence of herbicide treatment. Our results confirm that A. fatua MHR plants display constitutive changes in the levels of several GSH-related proteins.

Of all plant GSH-related enzymes, the GST superfamily is especially large and diverse [49,50]. Soluble GSTs are typically dimers of 24$27 \mathrm{kDa}$ subunits, with isoelectric points near pH 5 [31]. Higher plants have at least ten different GST classes, of which the predominant phi and tau classes have broad substrate specificities and are primarily responsible for herbicide detoxification [51]. GSTs conjugate GSH to oxidized xenobiotics as part of Phase II metabolism, and individual GSTs of several classes are key players in NTSR to herbicides [52]. For example, resistance to quinclorac in Echinochloa crus-galli was associated with increased expression of a GST [53], and transgenic overexpression of a lambda GST in O. sativa [54] or a Citrus sinensis tau GST with an altered binding site [55] in Nicotiana tabacum [56] conferred resistance to several herbicides. The best-characterized role of GSTs in NTSR is for the 'Peldon' MHR A. myosuroides population that is resistant to the PSII inhibitor chlorotoluron and several ACCase inhibitor graminicides. Early work showed that MHR plants had higher GST specific activity towards fenoxaprop-P-ethyl, elevated levels of immuno-recognized GST proteins, and higher concentrations of glutathione and hydroxymethylglutathione than susceptible plants [41]. Subsequently, Cummins, Bryant and Edwards [13] reported that antioxidant changes induced by herbicide safeners closely mirrored, but did not fully account for, the MHR phenotype. Finally and most recently, the same authors elegantly showed that MHR in A. myosuroides was conferred by overexpression of the phi class AmGSTF1, which acted not through traditional degradation, but through a novel and direct regulatory control on flavonoid metabolism [15].

In A. fatua, GSH affinity chromatography and 2D-DIGE revealed constitutively higher levels of three tau class (OsGSTU1, OsGSTU5, and OsGSTU27) GSTs and one phi class (OsGSTF3) GST in MHR4 as compared to HS1 plants. Tau and phi GSTs are the largest plant-specific class of GSTs with known roles in herbicide metabolism [11]. In this regard, Cho and Kong [57] showed that OsGSTF3 and OsGSTU5 had high specific activities towards several chloroacetanilide herbicides and the diphenylether herbicide fluorodifen, respectively. In addition to herbicide detoxification, the GST orthologs identified in this study also have roles in abiotic and biotic stress response. For example, OsGSTU5 was up-regulated in 0 . sativa plants in response to desiccation, salt, and cold stresses, while both OsGSTU1 and OsGSTU5 were up-regulated in arsenate-treated and Magnaporthe grisea-infected 0 . sativa plants [58]. In addition to the $A$. fatua proteins identified via 2D-DIGE having well-known GSH-binding roles in plants, we found constitutively lower levels of polyubiquitin, fructose-bisphosphate aldolase, phosphoribulokinase, and malate dehydrogenase in MHR4 as compared to HS1 plants. These proteins are known to bind or are regulated by GSH in non-plant systems, such as human polyubiquitin and fructosebisphosphate aldolase, which are reduced by GSH during recovery from oxidative stress $[59,60]$. Lower levels of these proteins may reflect a constitutively altered redox state in MHR4 plants.

OsGSTU5, OsGSTU1, and OsGSTF3 were each identified from two unique spots, as illustrated by the spot pairs $6 / 7,8 / 9$, and $10 / 11$, respectively, shown in Fig. 1. Similar 2D gel patterns for GSTs have been reported in maize [61] and other plant species [62], and are proposed to arise from differential oxidation of methionine and cysteine residues or partial protein degradation [63]. Individual GSTs are also regulated via post-translational phosphorylation [64]. The A. fatua protein spot 9 was predicted to contain a dehydrated glutamic acid residue, although the biological significance of this modification is unknown. Comparisons of the predicted GST peptide sequences reported here against $A$. fatua transcript sequences from our RNA-Seq transcriptome analysis (Keith et al. in press) revealed that annotations within each GST class 
agreed between the two independent analyses, but peptide sequences did not directly correlate to individual $A$. fatua transcripts (data not shown).

In untreated $A$. fatua, GST specific activity towards the model substrate CDNB was slightly but significantly higher in MHR than in HS plants, likely reflecting the constitutive changes in individual GSTs seen in our proteomic and immunoassays. However, the very low GST specific activities towards imazamethabenz-methyl and fenoxapropP-ethyl were not different between HS1 and MHR4 A. fatua plants, indicating that enhanced rates of metabolism are not directly responsible for the resistance phenotype. We did not test GST activities using hydroxymethylglutathione.

DHAR specific activity, a key step in the glutathione-ascorbate reactive oxygen species protective pathway [65], was also slightly but significantly higher in untreated MHR than HS plants. Elevated DHAR and GST(CDNB) activities were also reported for untreated MHR A. myosuroides plants [41]. GSH-dependent peroxidase (GPx) activity, which reduces oxidative stress-generated hydroperoxides to monohydroxyalcohols, and HED thioltransferase activity were not significantly different between untreated MHR and HS A. fatua plants.

Safeners like mefenpyr are chemicals applied with herbicides that protect cereal crops from injury while not reducing weed control efficacy [66]. They function by inducing herbicide catabolic enzymes in crop plants, such as GSTs, P450s, and glucosyltransferases [43]. In particular, mefenpyr is known to safen ACCase-inhibitor herbicides like fenoxaprop-P-ethyl [43] and the ALS inhibitor mesosulfuron-methyl [67] in cereals. An ongoing question concerning safener use is whether they also induce similar systems in weedy plants, especially in MHR populations, and thus enhance resistance levels. We treated MHR A. fatua plants with a range of herbicide doses with and without mefenpyr to examine this question in detail. Our results show that mefenpyr reduced the efficacy of low doses of fenoxaprop-P-ethyl on MHR4 but not MHR3 plants. Mefenpyr treatment of MHR3 or MHR4 A. fatua plants also partially reduced the efficacy of thiencarbazone-methyl or mesosulfuron-methyl, respectively. These mixed results indicate that mefenpyr may slightly reduce herbicide efficacy on MHR A. fatua populations, but that the effect is likely herbicide- and population-specific. In this regard, our results also support current resistance management recommendations of applying full labeled doses, to avoid the potential rapid evolution of MHR under reduced doses [68]. The subtle differences between MHR3 and MHR4 responses to mefenpyr-containing treatments likely reflect alterations in their resistance mechanisms to individual ALS (thiencarbazone-methyl and mesosulfuron-methyl) and ACCase (fenoxaprop-P-ethyl) inhibitors. In support of this idea, we previously documented significant $\mathrm{ED}_{50}$ (dose causing $50 \%$ injury) differences between these two populations for paraquat [6], difenzoquat, flucarbazone, and imazamethabenz-methyl [17]. In contrast to MHR4 A. fatua, MHR A. myosuroides plants were not rendered more resistant to fenoxaprop-P-ethyl by the addition of mefenpyr [13].

For HS A. fatua plants, mefenpyr did not reduce the efficacy of thiencarbazone-methyl or mesosulfuron-methyl, and slightly reduced the efficacy of a low dose of fenoxaprop-P-ethyl, in contrast to its effects in cereal crops and HS A. myosuroides [13]. Additionally, the lack of effect of the GST inhibitor NBD-Cl on fenoxaprop-P-ethyl activity against HS or MHR A. fatua is in stark contrast to its effects on MHR A. myosuroides, where it significantly enhanced the phytotoxicity of chlorotoluron, fenoxaprop-P-ethyl, and clodinafop-propargyl [15]. Such comparisons show that HS and MHR populations of these two weedy monocot species respond differently to a GST inducer (mefenpyr) and inhibitor (NBD-Cl), supporting the idea that subtle differences in their xenome activation regulatory networks can give rise to quantitatively different MHR phenotypes. The growth stimulation of $A$. fatua plants caused by mefenpyr treatment was similar to that reported for wheat [43], while a similar effect by NBD-Cl was unexpected, and deserves further scrutiny.
Immunoassays revealed detectable increases in proteins recognized by anti-lambda, -tau, and -phi GST antibodies in untreated MHR versus HS A. fatua plants. These changes are similar to those reported for untreated A. myosuroides plants, including the detection of specific phi GSTs in MHR but not HS plants [13]. However, none of the immunoreactive GST proteins in HS or MHR A. fatua were induced to higher levels after treatment with three different herbicide mechanisms of action, in direct contrast to results from A. myosuroides [69], maize [70], and other species [71]. The A. fatua results are supported by a lack of transcriptional induction of four GSTs in response to flucarbazone-sodium treatment of HS plants (Keith et al. in press). Together, these findings indicate that constitutively increased GST levels in A. fatua plants may be sufficient for their possible role(s) in the MHR phenotype without the need for additional induction after herbicide treatment, or that they are unrelated.

Anti-lambda, -tau, and -phi GST antibodies recognized three, four, and four proteins, respectively, in allohexaploid A. fatua plants, as compared to one, one, and two proteins in the closely related diploid $A$. myosuroides, respectively [13]. These differences likely reflect gene duplication events (i.e., creation of homoeologs) following polyploidization of A. fatua from its diploid progenitors [72]. The resulting greater heterozygosity in A. fatua and other polyploids likely contributes to their overrepresentation among successful weedy species [73] and has provided a diverse genetic background for the evolution of MHR. For A. fatua, enhanced heterozygosity conferred by hexaploidy is likely offset in part by its predominantly autogamous pollination behavior. The prevailing view that NTSR evolves through selection and introgression of individual alleles through outcrossing [74] may thus be less applicable to this species. MHR and HR populations from the Poaceae are over-represented [4] among 'the world's worst weeds' families [75], and HR A. fatua populations probably have a greater worldwide economic impact than those of any other species [1].

In conclusion, the GSTs and other GSH-related proteins described here do not appear to be directly involved in enhanced rates of fenoxaprop-P-ethyl and imazamethabenz-methyl metabolism in MHR A. fatua. Instead, we propose that constitutively elevated GST(CDNB) and DHAR enzyme activities, as well as the increased levels of lambda, phi, and tau GSTs documented here are representative of a larger, more global suite of abiotic stress-related changes in MHR plants. We recently showed that a significant number of such transcripts and proteins are constitutively elevated in MHR A. fatua plants (Keith et al. in press), similar to other stress-tolerant plant species and varieties. Of 25 transcripts examined in detail, differential expression of 21 co-segregated with the flucarbazone resistance phenotype in $\mathrm{F}_{3}$ families. Further, 15 transcripts and proteins constitutively expressed at higher levels in MHR plants have functions in redox maintenance and stress response (Keith et al. in press). It thus appears that intensive herbicide usage over several decades has selected for MHR plants with a constitutively induced abiotic stress-response pathway, and that elements of this pathway overlap with xenome activation.

\section{Acknowledgements}

Polyclonal antisera to the maize phi class GST ZmGSTF1-2 [39] and the wheat tau GST TaGSTU1-1 [38] were graciously provided by Dr. Melissa Brazier-Hicks, University of York, UK. Polyclonal antisera to the wheat lambda class GST TaCla30 [37] were graciously provided by Dr. Frederica Theodoulou, Rothamsted Research, UK.

The excellent technical assistance of Hayden Bateman, Mark Boyd, Shane Cartularo, Patrick Certain, Tara Donohoe, Alex Griffin, and Katie Steward is much appreciated. This work was partially supported by USDA-NIFA-AFRI grants 2012-67013-19467 and 2016-67013-24888, US EPA Strategic Agricultural Initiative grant X8-97873401-0, Bayer CropScience, the Montana Noxious Weed Trust Fund, the Montana Wheat and Barley Committee, and the Montana Agricultural Experiment Station. The proteomics, metabolomics, and mass spectrometry 
facility at MSU receives support from the Murdock Charitable Trust and Montana INBRE under Award Number P20GM103474 from the National Institutes of Health (NIGMS).

\section{Appendix A. Supplementary data}

Supplementary data to this article can be found online at http://dx. doi.org/10.1016/j.pestbp.2017.06.007.

\section{References}

[1] I. Heap, The International Survey of Herbicide Resistant Weeds, 2017.

[2] D.L. Shaner, R.B. Lindenmeyer, M.H. Ostlie, What have the mechanisms of resistance to glyphosate taught us? Pest Manag. Sci. 68 (2012) 3-9.

[3] C. Délye, J. Gardin, K. Boucansaud, B. Chauvel, C. Petit, Non-target-site-based resistance should be the centre of attention for herbicide resistance research: Alopecurus myosuroides as an illustration, Weed Res. 51 (2011) 433-437.

[4] G. Holm, D. Phicknett, J. Pancho, J. Herberger, The World's Worst Weeds. Distribution and Biology, Krieger Publication Company, Hawaii, 1991.

[5] H.J. Beckie, A. Francis, L.M. Hall, The biology of Canadian weeds. 27. Avena fatua L (updated), Can. J. Plant Sci. 92 (2012) 1329-1357.

[6] B. Keith, E. Lehnhoff, E. Burns, F. Menalled, W. Dyer, Characterisation of Avena fatua populations with resistance to multiple herbicides, Weed Res. 55 (2015) 621-630.

[7] A.J. Kern, C.T. Colliver, B.D. Maxwell, P.K. Fay, W.E. Dyer, Characterization of wild oat (Avena fatua L.) populations and an inbred line with multiple herbicide resistance, Weed Sci. (1996) 847-852.

[8] V.K. Nandula, C.G. Messersmith, Imazamethabenz-resistant wild oat (Avena fatua L.) is resistant to diclofop-methyl, Pestic. Biochem. Physiol. 74 (2002) 53-61.

[9] E.A. Lehnhoff, B.K. Keith, W.E. Dyer, F.D. Menalled, Impact of biotic and abiotic stresses on the competitive ability of multiple herbicide resistant wild oat (Avena fatua), PLoS One 8 (2013), e64478.

[10] R. Edwards, D.P. Dixon, I. Cummins, M. Brazier-Hicks, M. Skipsey, New perspectives on the metabolism and detoxification of synthetic compounds in plants, Organic Xenobiotics and Plants, Springer 2011, pp. 125-148.

[11] I. Cummins, D.P. Dixon, S. Freitag-Pohl, M. Skipsey, R. Edwards, Multiple roles for plant glutathione transferases in xenobiotic detoxification, Drug Metab. Rev. 43 (2011) 266-280.

[12] P.J. Hatton, D. Dixon, D.J. Cole, R. Edwards, Glutathione transferase activities and herbicide selectivity in maize and associated weed species, Pestic. Sci. 46 (1996) 267-275.

[13] I. Cummins, D.N. Bryant, R. Edwards, Safener responsiveness and multiple herbicide resistance in the weed black-grass (Alopecurus myosuroides), Plant Biotechnol. J. 7 (2009) 807-820.

[14] R. Scalla, A. Roulet, Cloning and characterization of a glutathione S-transferase induced by a herbicide safener in barley (Hordeum vulgare), Physiol. Plant. 116 (2002) 336-344.

[15] I. Cummins, D.J. Wortley, F. Sabbadin, Z. He, C.R. Coxon, H.E. Straker, J.D. Sellars, K. Knight, L. Edwards, D. Hughes, Key role for a glutathione transferase in multipleherbicide resistance in grass weeds, Proc. Natl. Acad. Sci. 110 (2013) 5812-5817.

[16] G. Ricci, F. De Maria, G. Antonini, P. Turella, A. Bullo, L. Stella, G. Filomeni, G. Federici, A.M. Caccuri, 7-Nitro-2,1,3-benzoxadiazole derivatives, a new class of suicide inhibitors for glutathione S-transferases. Mechanism of action of potential anticancer drugs, J. Biol. Chem. 280 (2005) 26397-26405.

[17] E.A. Lehnhoff, B.K. Keith, W.E. Dyer, R.K. Peterson, F. Menalled, Multiple herbicide resistance in wild oat and impacts on physiology, germinability, and seed production, Agron. J. 105 (2013) 854-862.

[18] J. Naylor, S. Jana, Genetic adaptation for seed dormancy in Avena fatua, Can. J. Bot. 54 (1976) 306-312.

[19] R.R. Johnson, H.J. Cranston, M.E. Chaverra, W.E. Dyer, Characterization of cDNA clones for differentially expressed genes in embryos of dormant and nondormant Avena fatua L. caryopses, Plant Mol. Biol. 28 (1995) 113-122.

[20] M.M. Bradford, A rapid and sensitive method for the quantitation of microgram quantities of protein utilizing the principle of protein-dye binding, Anal. Biochem. 72 (1976) 248-254.

[21] M.G. Epstein, B.D. Reeves, W.S. Maaty, D. Fouchard, E.A. Dratz, B. Bothner, P.A. Grieco, Enhanced sensitivity employing zwitterionic and pI balancing dyes (Z CyDyes) optimized for 2D-gel electrophoresis based on side chain modifications of CyDye fluorophores. New tools for use in proteomics and diagnostics, Bioconjug. Chem. 24 (2013) 1552-1561.

[22] W.S. Maaty, K. Selvig, S. Ryder, P. Tarlykov, J.K. Hilmer, J. Heinemann, J. Steffens, J.C. Snyder, A.C. Ortmann, N. Movahed, Proteomic analysis of Sulfolobus solfataricus during Sulfolobus turreted icosahedral virus infection, J. Proteome Res. 11 (2012) $1420-1432$.

[23] N. Dyballa, S. Metzger, Fast and sensitive colloidal coomassie G-250 staining for proteins in polyacrylamide gels, J. Vis. Exp. (2009) e1431.

[24] A. Shevchenko, H. Tomas, J. Havli, J.V. Olsen, M. Mann, In-gel digestion for mass spectrometric characterization of proteins and proteomes, Nat. Protoc. 1 (2006) 2856-2860.

[25] K.E. Mason, J.K. Hilmer, W.S. Maaty, B.D. Reeves, P.A. Grieco, B. Bothner, A.M. Fischer, Proteomic comparison of near-isogenic barley (Hordeum vulgare L.) germplasm differing in the allelic state of a major senescence QTL identifies numerous proteins involved in plant pathogen defense, Planta (2016).
[26] M. Vaudel, J.M. Burkhart, R.P. Zahedi, E. Oveland, F.S. Berven, A. Sickmann, L. Martens, H. Barsnes, PeptideShaker enables reanalysis of MS-derived proteomics data sets, Nat. Biotechnol. 33 (2015) 22-24.

[27] M. Wang, M. Weiss, M. Simonovic, G. Haertinger, S.P. Schrimpf, M.O. Hengartner, C. von Mering, PaxDb, a database of protein abundance averages across all three domains of life, Mol. Cell. Proteomics 11 (2012) 492-500.

[28] W.H. Habig, M.J. Pabst, W.B. Jakoby, Glutathione S-transferases the first enzymatic step in mercapturic acid formation, J. Biol. Chem. 249 (1974) 7130-7139.

[29] C.J. Weydert, J.J. Cullen, Measurement of superoxide dismutase, catalase and glutathione peroxidase in cultured cells and tissue, Nat. Protoc. 5 (2010) 51-66.

[30] R. Edwards, D.P. Dixon, Plant glutathione transferases, Methods Enzymol. 401 (2005) 169-186.

[31] D.P. Dixon, B.G. Davis, R. Edwards, Functional divergence in the glutathione transferase superfamily in plants identification of two classes with putative functions in redox homeostasis in Arabidopsis thaliana, J. Biol. Chem. 277 (2002) 30859-30869.

[32] S. Pintado, M. Ruiz Montoya, J.M. Rodríguez Mellado, Protonation - dissociation reactions of imazamethabenz-methyl and imazamethabenz-acid in relation to their soil sorption and abiotic degradation, J. Agric. Food Chem. 57 (2009) 11292-11296.

[33] M.A.S. Marles, M.D. Devine, J.C. Hall, Herbicide resistance in Setaria viridis conferred by a less sensitive form of acetyl coenzyme A carboxylase, Pestic. Biochem. Physiol. 46 (1993) 7-14.

[34] R Core Team, R: A Language and Environment for Statistical Computing, R Foundation for Statistical Computing, Vienna, Austria, 2016.

[35] D.W. Cleveland, S.G. Fischer, M.W. Kirschner, U.K. Laemmli, Peptide mapping by limited proteolysis in sodium dodecyl sulfate and analysis by gel electrophoresis, J. Biol. Chem. 252 (1977) 1102-1106.

[36] D.F. Hochstrasser, M.G. Harrington, A.-C. Hochstrasser, M.J. Miller, C.R. Merril, Methods for increasing the resolution of two-dimensional protein electrophoresis, Anal. Biochem. 173 (1988) 424-435.

[37] F. Theodoulou, I. Clark, K. Pallett, D. Hallahan, Nucleotide sequence of Cla 30 (accession no. Y17386), a xenobiotic-inducible member of the GST superfamily from Triticum aestivum L. Plant Physiol. 119 (1999) 1567.

[38] I. Cummins, D.J. Cole, R. Edwards, Purification of multiple glutathione transferases involved in herbicide detoxification from wheat (Triticum aestivum L.) treated with the safener fenchlorazole-ethyl, Pestic. Biochem. Physiol. 59 (1997) 35-49.

[39] D.P. Dixon, D.J. Cole, R. Edwards, Purification, regulation and cloning of a glutathione transferase (GST) from maize resembling the auxin-inducible type-III GSTs, Plant Mol. Biol. 36 (1998) 75-87.

[40] C.A. Schneider, W.S. Rasband, K.W. Eliceiri, NIH image to Image]: 25 years of image analysis, Nat. Methods 9 (2012) 671-675.

[41] I. Cummins, S. Moss, D.J. Cole, R. Edwards, Glutathione transferases in herbicide-resistant and herbicide-susceptible black-grass (Alopecurus myosuroides), Pestic. Sci. 51 (1997) 244-250.

[42] I. Jablonkai, Herbicide Metabolism in Weeds-Selectivity and Herbicide Resistance, 2015.

[43] V.L. Taylor, I. Cummins, M. Brazier-Hicks, R. Edwards, Protective responses induced by herbicide safeners in wheat, Environ. Exp. Bot. 88 (2013) 93-99.

[44] F.L. Theodoulou, I.M. Clark, X.L. He, K.E. Pallett, D.J. Cole, D.L. Hallahan, Co-induction of glutathione-S-transferases and multidrug resistance associated protein by xenobiotics in wheat, Pest Manag. Sci. 59 (2003) 202-214.

[45] M. Brazier, D.J. Cole, R. Edwards, O-Glucosyltransferase activities toward phenolic natural products and xenobiotics in wheat and herbicide-resistant and herbicidesusceptible black-grass (Alopecurus myosuroides), Phytochemistry 59 (2002) 149-156.

[46] Y. Fang, H. Lu, S. Chen, K. Zhu, H. Song, H. Qian, Leaf proteome analysis provides insights into the molecular mechanisms of bentazon detoxification in rice, Pestic. Biochem. Physiol. 125 (2015) 45-52.

[47] C. Agrawal, S. Sen, S. Singh, S. Rai, P.K. Singh, V.K. Singh, L. Rai, Comparative proteomics reveals association of early accumulated proteins in conferring butachlor tolerance in three N 2-fixing Anabaena spp. J. Proteome 96 (2014) 271-290.

[48] A.P. Smith, B.P. DeRidder, W.-J. Guo, E.H. Seeley, F.E. Regnier, P.B. Goldsbrough, Proteomic analysis of Arabidopsis glutathione S-transferases from benoxacor-and copper-treated seedlings, J. Biol. Chem. 279 (2004) 26098-26104.

[49] E. Chronopoulou, K. Kontouri, M. Chantzikonstantinou, F. Pouliou, F. Perperopoulou, G. Voulgari, E. Bosmali, I. Axarli, I. Nianiou-Obeidat, P. Madesis, Plant glutathione transferases: structure, antioxidant catalytic function and in planta protective role in biotic and abiotic stress, Curr. Chem. Biol. 8 (2014) 58-75.

[50] N.E. Labrou, A.C. Papageorgiou, O. Pavli, E. Flemetakis, Plant GSTome: structure and functional role in xenome network and plant stress response, Curr. Opin. Biotechnol. 32 (2015) 186-194.

[51] R. Edwards, D.P. Dixon, The Role of Glutathione Transferases in Herbicide Metabolism, Sheffield Academic Press, Sheffield, UK, 2000.

[52] J.P. Reade, L.J. Milner, A.H. Cobb, A role for glutathione S-transferases in resistance to herbicides in grasses, Weed Sci. 52 (2004) 468-474.

[53] G. Li, S. Wu, R. Yu, T. Cang, L. Chen, X. Zhao, L. Cai, C. Wu, Identification and expression pattern of a glutathione S-transferase in Echinochloa crus-galli, Weed Res. 53 (2013) 314-321.

[54] T. Hu, A glutathione-S-transferase confers herbicide tolerance in rice, Crop Breed. Appl. Biotechnol. 14 (2014) 76-81.

[55] A.R. Lo Piero, V. Mercurio, I. Puglisi, G. Petrone, Different roles of functional residues in the hydrophobic binding site of two sweet orange tau glutathione S-transferases, FEBS J. 277 (2010) 255-262.

[56] L.L. Cicero, P. Madesis, A. Tsaftaris, A.R.L. Piero, Tobacco plants over-expressing the sweet orange tau glutathione transferases (CSGSTUs) acquire tolerance to the diphenyl ether herbicide fluorodifen and to salt and drought stresses, Phytochemistry 116 (2015) 69-77. 
[57] H.Y. Cho, K.H. Kong, Study on the biochemical characterization of herbicide detoxification enzyme, glutathione S-transferase, Biofactors 30 (2007) 281-287.

[58] M. Jain, C. Ghanashyam, A. Bhattacharjee, Comprehensive expression analysis suggests overlapping and specific roles of rice glutathione $S$-transferase genes during development and stress responses, BMC Genomics 11 (2010) 1.

[59] J. Jahngen-Hodge, M.S. Obin, X. Gong, F. Shang, T.R. Nowell, J. Gong, H. Abasi, J. Blumberg, A. Taylor, Regulation of ubiquitin-conjugating enzymes by glutathione following oxidative stress, J. Biol. Chem. 272 (1997) 28218-28226.

[60] J. Bond, M. Offermann, Initial events in the degradation of soluble cellular enzymes: factors affecting the stability and proteolytic susceptibility of fructose-1, 6bisphosphate aldolase, Acta Biol. Med. Ger. 40 (1980) 1365-1374.

[61] R. Edwards, D.D. Buono, M. Fordham, M. Skipsey, M. Brazier, D.P. Dixon, I. Cummins, Differential induction of glutathione transferases and glucosyltransferases in wheat, maize and Arabidopsis thaliana by herbicide safeners, Z. Naturforsch. C 60 (2005) 307-316.

[62] D.P. Dixon, R. Edwards, Selective binding of glutathione conjugates of fatty acid derivatives by plant glutathione transferases, J. Biol. Chem. 284 (2009) 21249-21256.

[63] D.P. Dixon, R. Edwards, Glutathione transferases, The Arabidopsis Book 2010 , p. e0131.

[64] I. Puglisi, L.L. Cicero, A.R.L. Piero, The glutathione S-transferase gene superfamily: an in silico approach to study the post translational regulation, Biodegradation 24 (2013) 471-485.

[65] K. Asada, Production and scavenging of reactive oxygen species in chloroplasts and their functions, Plant Physiol. 141 (2006) 391-396.

[66] H. Kraehmer, B. Laber, C. Rosinger, A. Schulz, Herbicides as weed control agents: state of the art: I. Weed control research and safener technology: the path to modern agriculture, Plant Physiol. 166 (2014) 1119-1131.

[67] E. Hacker, H. Bieringer, L. Willms, K. Lorenz, H. Koecher, H. Huff, G. Borrod, R. Brusche, Mesosulfuron-methyl-a new active ingredient for grass weed control in cereals, The BCPC Conference: Weeds, 2001, Volume 1 and Volume 2. Proceedings of an International Conference Held at the Brighton Hilton Metropole Hotel, Brighton, UK, 12-15 November 2001, British Crop Protection Council 2001, pp. 43-48.

[68] P. Neve, S. Powles, High survival frequencies at low herbicide use rates in populations of Lolium rigidum result in rapid evolution of herbicide resistance, Heredity 95 (2005) 485-492.

[69] I. Cummins, D.J. Cole, R. Edwards, A role for glutathione transferases functioning as glutathione peroxidases in resistance to multiple herbicides in black-grass, Plant J. 18 (1999) 285-292.

[70] S. Pang, L. Duan, Z. Liu, X. Song, X. Li, C. Wang, Co-induction of a glutathione-S-transferase, a glutathione transporter and an $\mathrm{ABC}$ transporter in maize by xenobiotics, PLoS One 7 (2012), e40712.

[71] T. Flury, D. Adam, K. Kreuz, A 2, 4-D-inducible glutathione S-transferase from soybean (Glycine max). Purification, characterisation and induction, Physiol. Plant. 94 (1995) 312-318.

[72] Q. Yang, L. Hanson, M. Bennett, I. Leitch, Genome structure and evolution in the allohexaploid weed Avena fatua L.(Poaceae), Genome 42 (1999) 512-518.

[73] M. te Beest, J.J. Le Roux, D.M. Richardson, A.K. Brysting, J. Suda, M. Kubešová, P. Pyšek, The more the better? The role of polyploidy in facilitating plant invasions, Ann. Bot. (2011), mcr277.

[74] C. Delye, Unravelling the genetic bases of non-target-site-based resistance (NTSR) to herbicides: a major challenge for weed science in the forthcoming decade, Pest Manag. Sci. 69 (2013) 176-187.

[75] J.S. Holt, S.R. Welles, K. Silvera, I.M. Heap, S.M. Heredia, A. Martinez-Berdeja, K.T Palenscar, L.C. Sweet, N.C. Ellstrand, Taxonomic and life history bias in herbicide resistant weeds: implications for deployment of resistant crops, PLoS One 8 (2013), e71916. 